\title{
Investigating Functional Roles on Engineering Student Teams: A Developmental Perspective
}

\author{
Ms. Jeannie Brown Leonard, Dr. Linda C. Schmidt, Dr. Paige E. Smith, \\ \& Dr. Janet A. Schmidt \\ University of Maryland, College Park
}

\section{Introduction}

Teams are a principal but unpredictable learning environment in engineering. Being assigned a team project in an engineering course is like drawing a Chance card in the game of Monopolyß. Once in a while you advance to GO but more often you must go directly to Jail or face some other setback. Well-functioning teams have been shown to improve learning and retention in non-engineering fields, especially for members of underrepresented groups $s_{1,2,3,4,5}$. Both students and instructors recognize that high degrees of team cohesion and collective efficacy (i.e., team members' beliefs about their ability to be effective at their task as a group) are related to good team performance ${ }^{6}$. At the opposite end of the spectrum, poor team experiences can leave individuals with adequate grades on their transcripts but low subject matter proficiency, poor comprehension of the team process, and low self-efficacy. Both faculty and students will benefit from improved knowledge about enhancing team effectiveness.

Engineering educators need more guidance on how to design team experiences for students that maximize their strengths as informal learning communities and minimize their weaknesses.

There are successes in developing multidisciplinary, multi-semester project assignments. Three exemplars include the vertically-integrated project teams at Purdue University in the Engineering Projects in Community Service (EPICS) program ${ }^{7}$; the Engineering Clinic sequence of training at Rowan University ${ }^{8}$; and the Computer Science senior design course at the United States Military Academy 9 . These programs are the exception and not the rule. Single courses can be powerful learning environments when students and instructors are aware of the effects course structure, including project assignments, have on student behavior within the team.

One of the most consistent themes in the literature on teams is the importance of team roles ${ }^{10,11}$. The focus on roles is linked to the idea that certain predictable processes and behaviors must occur, represented by roles such as Facilitator or Leader, if a team is to be successful. Increasing the awareness (or training) of team members to these roles increases the chances that the appropriate behaviors will occur and the team will be successful. Ironically, the roles most often identified and studied in the engineering education literature are those characterizing nontechnical activities and behaviors ${ }^{10,11,12,13}$. One example of an insightful study is Knecht's ${ }^{12}$ work in teaching first-year students about the need for balance between "task" and "team" roles as defined by Eberhardt. This role set was used in an earlier study on gendered role behavior ${ }^{14}$. Clearly, process roles are critical to smooth team operation and engineers need to be proficient in performing such process roles.

"Proceedings of the 2005 American Society for Engineering Education Annual Conference \& Exposition Copyright (c) 2005, American Society for Engineering Education” 
Engineering educators have overlooked team roles specific to engineering student project teams. These are roles related to the accomplishment of the assigned project and require specific functional skills such as design (Design Specialist), construction (Builder), report writing (Technical Writer), computational expertise (Computer Programmer), or analysis (Number Cruncher). By dividing the tasks required to accomplish a project by functional area, the team may produce a strong product, but students' understanding may be limited to their area of contribution. This is the specialization model of teaming that is pervasive in industrial settings where project completion is emphasized over learning. In some classroom project situations, technical specialization by engineering discipline is necessary for the success of the effort (e.g., senior capstone courses or national competition project courses). However, wide spread specialization throughout the undergraduate experience, especially in courses serving first and second year students, interferes with the learning goals of engineering education.

In an effort to understand better the importance of functional roles in engineering student teams, we conducted a pilot study using a qualitative methodology funded under the NSF ASA Grant Award Number DUE-0243265. These data provided evidence of students' tendency to perform similar functions across team experiences throughout the curriculum. Indeed, by the senior year, students are skilled at assembling teams with a range of functional skills covering all the specialties needed to complete the assigned $\operatorname{project}^{15}$. Some students recognized this division of labor compromised overall learning. However, students justified the approach as necessary to ensure the creation of an outstanding product within a limited timeframe.

To understand better this tension between specialization and breadth of learning, the data in this study were analyzed to capture the functional role-taking behavior within the various team experiences across the mechanical engineering curriculum. We conducted focus groups with existing teams from freshman, sophomore, junior, and senior-level courses within mechanical engineering to learn about student experiences with functional roles on project teams. In addition, instructors of these courses were interviewed to learn about faculty perspectives on whether or not functional roles affect student team projects. This paper will focus on the changes in functional team roles and perspectives over the course of the undergraduate engineering curriculum.

\section{Teams and Learning}

Developing team experiences for undergraduate students that simulate professional "real world" problems creates a natural tension with the obligation to teach course content and skills. The pressure by employers to produce graduates who are better prepared to work on multidisciplinary teams is one reason faculty incorporate student project teams into their courses. Yet, mimicking the professional world may produce performance measures that value product quality over individual learning in the classroom. Professional settings, which value efficiency and high quality, expect employees to be specialists (depth at the expense of breadth). Educators value content and conceptual mastery with an appropriate balance of depth and breath. Another difficulty with adopting the industrial project team model is that student teams will not and cannot duplicate the diversity of experience, both in team process and functional expertise, of a team in an engineering firm.

"Proceedings of the 2005 American Society for Engineering Education Annual Conference \& Exposition Copyright (C) 2005, American Society for Engineering Education” 
Johnson ${ }^{16}$ recommended rotating roles within a team as one way to encourage greater mastery of the project and the course material it represents. Certainly, the ways assignments are designed and presented to students contribute to the approach students will take. Given the distinctive demands of engineering project teams in a university context, the emphasis must be on student learning rather than efficiency or, perhaps, even overall product quality. Engineering educators should not be satisfied unless all students gain proficiency in all aspects of the subject matter addressed by a particular project. For those students who are prone to specializing and offering their talents in a variety of team contexts, what interventions, if any, might enhance their learning?

\section{Research Questions}

Curious about how students experience team roles as they progress through the mechanical engineering curricula, the research team queried existing teams in key mechanical engineering courses in the first, second, third, and fourth year. The overarching questions guiding the investigation were:

- What specific functional roles can be identified in engineering project teams?

- Is there a connection between functional role performance and the learning of engineering content and skills?

- Do upper-level students who have had a variety of team experiences gravitate towards roles (process or functional) they have had in the past?

- What insights do faculty have about the team project experience in their courses?

\section{Method}

Five teams from selected courses in mechanical engineering participated in focus groups: Two teams of freshman or transfer students taking Introduction to Engineering Design (ENES 100), one team of sophomores enrolled in Mechanics of Materials (ENES 220), one team of juniors enrolled in Statistical Methods for Product and Process Development (ENME 392), and one team of seniors in Integrated Product and Process Development II, the capstone experience (ENME 472). Focus groups offer an efficient means of acquiring detailed information on group perceptions ${ }^{17}$. The focus group methodology provided researchers with access to current team experiences with all team members present. Each team member was encouraged to participate and the group context allowed individuals to build on or to refute the comments shared by other members of the group. Similarly, the focus group facilitator could pursue ideas and themes introduced by group members that were not part of the original protocol.

Using existing, in tact teams may have affected the level of candor and engagement in the focus group conversation. Vaughn, Schumm, and Sinagub ${ }^{17}$ recommended creating focus groups comprised of strangers to prevent any inhibition on the part of participants. In an effort to measure the extent to which individual participants were guarded in their comments, each person completed a brief, anonymous questionnaire at the conclusion of the session. Participants indicated the degree to which they were comfortable sharing their ideas during the conversation. Of the 26 participants across all focus groups, 23 indicated that they agreed or strongly agreed with the statement "I did not withhold or edit my comments because my teammates were

"Proceedings of the 2005 American Society for Engineering Education Annual Conference \& Exposition Copyright (C) 2005, American Society for Engineering Education” 
present." Similarly, 25 of 26 agreed or strongly agreed with the statement "I felt comfortable during this conversation." Other possible limitations of the focus group approach include challenges related to identifying and scheduling the groups, the need for skilled moderators, and the potential for the conversation to drift off topic ${ }^{18}$. A final limitation of this study concerns the cross-sectional sample. The teams representing each year in the mechanical engineering curriculum were different, thereby limiting the developmental conclusions drawn from these data.

The questions included in the focus group protocol included introductory questions about the team project and course context, as well as questions about team functioning, functional roles, process roles, and questions about mastery of engineering content. All probes were open ended. Every effort was made to construct questions that did not influence responses.

The five faculty teaching the courses from which the teams were recruited participated in interviews. Faculty were asked to discuss the team project in their courses and describe a wellfunctioning team. Again, open-ended probes were used to elicit candid responses. Questions were shaped in part by the themes and content raised by the student team from the corresponding course.

The focus groups and interviews were organized and conducted in the 2003-04 academic year by the Principal Investigators and graduate research assistant using the focus group and interview protocols. Examples of specific questions related to roles students take in engineering project teams include:

- What functions do you prefer to do when working on a team?

- Are there roles or functions of working on a team that you like to do, but for some reason, seldom get a chance to do? If so, what gets in the way?

- Do you use the team experience as an opportunity to learn new skills? If not, why? If yes, please describe how or give examples.

- In different team settings do you find yourself performing the same tasks over and over? Is this by your choice? The team's choice?

- How are group dynamics and interactions managed in effective teams?

- What are the special group process roles you like to fill on project teams (e.g., leader, facilitator)?

Specific questions used in the faculty interviews to explore the team project assignment include:

- Do you assign students to team roles?

- Describe an effective student project team for this course.

- How do you know if your learning goals for the project have been met?

- What roles do you expect that students to perform on their teams?

- In what ways do these functional roles influence successful team functioning?

The focus groups and interviews were tape-recorded. To protect confidentiality, students selected pseudonyms for the conversations and faculty conversations were coded with the course number. The tapes were transcribed and a content analysis was conducted related to our key research questions. Each participant received a $\$ 20$ gift card from the university bookstore as compensation for participating in a focus group or interview. Although participants may have

"Proceedings of the 2005 American Society for Engineering Education Annual Conference \& Exposition Copyright (C) 2005, American Society for Engineering Education” 
gained new insights about their team activities or courses, no such benefits were expected or offered as an enticement to participants.

\section{Findings}

The content analysis identified several themes, three of which are central to this investigation: functional roles, learning, and role specialization. Each of these student-generated themes was explored in the faculty interviews as well. Both students and faculty expressed different strategies and approaches to the engineering student team depending on the course level. Tables $1-3$ in the Appendix contain a summary of the main themes for each level in the mechanical engineering course sequence. Defining characteristics of each theme are in bold type followed by evidence from the focus groups to support each characteristic.

\section{Functional Roles}

The students participating in the focus groups readily identified and named roles related to the tasks or technical skills they were contributing to the project (see Table 1). The specific roles mentioned were linked directly to the project assignment. The variety of functional roles across courses suggests that not all functional areas were needed for every project. For example, the web site developer for the ENES 100 team will contribute other skills to a subsequent team if a web site is not a part of the next team experience.

Although not a functional role, the position of leader was discussed in all focus groups. In the first-year teams, the presence of a team leader was emphasized as an essential role. Consistent with the teams representing the second and third year experiences, the leader contributed some functional or technical skill to the team in addition to his or her leadership role. The third-year team rotated the leader every two weeks as required by the assignment. Yet, by the final year, the need for a leader was eliminated. The senior team resisted the idea of a leader and, when pushed, identified the project manager as the team leader.

\section{Learning}

The second theme (see Table 2) highlights the connection between functional role performance and student learning. The students enrolled in the first-year course were making the transition from high school-style group projects to college level team projects. One team was comprised of members who preferred to work alone. Following some resistance to the team assignment, this team acknowledged the benefit of working together. The project helped team members learn about teamwork. The engineering content part of learning was viewed as secondary to group process skills. The general consensus from these team members was that the teacher was responsible for teaching them what they needed to know to do well on the project and the course overall. Some students took more responsibility for their own learning and sought outside resources as needed. Few viewed their peers as viable sources of information or assistance.

By the second year, the connection between the engineering course content and the project was clear. The students relied on the course to provide the tools needed to complete the team project. Peers offered some modest support, but the pressure to complete a complex task in a limited amount of time was a prominent concern. This team offered several creative suggestions to ensure all team members learned what they needed to know about the project.

"Proceedings of the 2005 American Society for Engineering Education Annual Conference \& Exposition Copyright (c) 2005, American Society for Engineering Education” 
The junior year team expressed some surprise that a team project was required in the statistics class. The project could tap only a subset of the skills and tools introduced by the course. According to the students, the person doing the data analysis (Number Cruncher) would, most likely, learn the most from the project. Students recognized that the nature and complexity of the team projects increased over time. The faculty member in this course required the role of team leader to rotate every two weeks. This attention to team process was not lost on the students. They noted that learning is as important as the final product, if not more important. They all agreed that the main purpose of the team project was to teach teamwork. The students also expressed a willingness to help their peers, in part because the process of teaching reinforced their own learning.

The senior capstone team agreed that the team project expectations were exceptionally complex and integrative. They were required to design a product that required a synthesis of all of their prior course work. These team members wanted and expected to learn from their peers. The team was comprised of individual members with special talents that could contribute to the final project. Learning from these specialized team members was desired, but when time was limited, it was not possible to teach someone else. The pressure of time also compromised the overall learning objectives for this project.

Over the four-year experience, then, the kind of learning that was encouraged on teams and within functional roles progresses from an emphasis on team process skills to a highly sophisticated and content rich capstone project. The one anomaly was the junior year course included in this investigation where team functioning also was emphasized. However the connection between the project and the course content was still clear. There was a growing confidence in one's peers as a legitimate source of information and guidance; most participants cited this growing trust from the perspective of being the tutor, rather than the one seeking help. In addition to an increased reliance on peers, students demonstrated an increased reliance on themselves in supporting their own learning. These trends are consistent with cognitive development patterns in college where learners move from being absolute knowers, dependent of external authority, to more independent and transitional knowers where they begin to view themselves as capable of creating knowledge ${ }^{19}$.

\section{Specialization}

It was clear that many students develop specialties that they were repeatedly called upon to contribute to their teams (see Table 3). Beginning with the first-year teams, students were taking on functional roles related to their self-reported strengths. These students did not have a history with each other, so the role assignments were made with less confidence. Students made the case that approaching projects in this way produces the best final product and offers novices a way to organize the team effort. Drawbacks to this divide and conquer approach were not mentioned. In fact, team members claimed their learning was enhanced and that these initial roles in no way predict or limit future roles on project teams.

In the second-year course, strengths and interests helped determine role assignments. Although still early in their college experience, some students recognized specialties that are prized by team members. Having specialists promises a better product and grade and offers other team

"Proceedings of the 2005 American Society for Engineering Education Annual Conference \& Exposition Copyright (C) 2005, American Society for Engineering Education” 
members a chance to learn something new. This latter benefit was realized only if there were built-in opportunities for sharing information within the team context. Since this coordination was rare, most students noted that specialists limit their learning.

The third-year team tried to craft the ideal ratio of specialists to non-specialists on a team. If half the team is comprised of specialists, then the team is ideally suited to have a great product because the non-specialists can fill in as needed. The value of specialists was accepted as always desirable.

The seniors noted that a person's specialty figured prominently in whether someone was invited to join the project team. The team was designed to have a range of talents represented. Duties were divided along expertise lines with some effort to share information and progress with the larger team. Specializing was viewed as essential to completing the monumental task at hand at a high quality standard. The product quality was paramount and learning certainly was compromised.

The evidence of specialization was very strong, but students argued that the team projects demand it. To be successful in completing a strong project, everyone must contribute his or her talents. One senior described himself as a "jack-of-all-trades," yet he was performing a functional role he had performed in a previous team. No one had performed only one role throughout their college career, but the recurring patterns were clear.

\section{Faculty Insights}

What insights did the faculty have about the team project experience in their courses? Tables $4-$ 6 in the appendix capture faculty perspectives along the same three themes presented for the students: functional roles, learning, and role specialization.

\section{Functional Roles}

In general, faculty were not surprised that project teams divided up the work necessary to complete the project along functional lines (see Table 4). Although the faculty never prescribed specific roles, the roles students reported made sense to them. In the introductory engineering class, student functional roles mirrored the delineations made by the professor in making initial team assignments. Although presented with some training on team skills, students were given a lot of freedom in how they decided to approach their project.

In the second-year class, very little attention was given to team formation and team process. The students were expected to decide which roles to take and how to approach the project. The faculty member offered some direction about what steps needed to be taken to complete the project. The functional roles identified by the students corresponded to these prompts.

The students in the junior level class mentioned functional roles that made sense to the professor. The distribution seemed efficient and fair from the faculty member's perspective. Since the project required the application of certain skill sets, having those talents represented on the team would be helpful. Yet, the faculty member conceded that this approach means that not all students will develop those skills. 
In the capstone course, the faculty member discouraged the designation of a specific group leader and expected students to be proficient in team dynamics. The instructor was surprised by the functional roles reported by the team and was unaware of the approach taken by any given team. He expected the team to divide the workload, but assumed that equity in terms of the work assigned would be the guiding issue.

Little to no attention was given to functional roles by the faculty. In the first and second year courses, faculty offered some guidance to students about the scope of the project and the component parts that needed to be considered. By the third and fourth year, however, faculty were determined to let students make independent choices about how to approach the project. The only exception was the directive in the third year class to rotate team leaders every two weeks.

\section{Learning}

Faculty reported a range of learning goals for the projects embedded in their courses (see Table 5). In the introductory course, the expectation was for students to gain a broad understanding of engineering design principles and to be exposed to a number of areas within engineering. The hands-on nature of the project also provided an appealing outlet for some learning styles. If a team divided the project into parts based on functional areas, the professor did not expect individual team members to master the specialty of another team member. Through testing, the faculty member was able to determine individual student mastery of the course content.

The instructor of the second-year course acknowledged that team project experiences vary widely and depend in part on faculty attitude. Students often complained about the team project assignment; they were more interested in spending their time on tasks that contribute more to their grades than the project. This instructor saw a gap between his expectations for students (attending to detail, checking each others work) and what they actually did. Since the only feedback students received on their project was a final grade, there was no incentive to value the process as much as or more than the product.

The faculty member teaching the third-year course was confident that rotating the leadership role promoted awareness and responsibility among team members. Yet, this broad perspective may not translate into improved learning. He did not know for sure that students achieved the learning goals he had for the project.

For the senior capstone, the faculty member fully expected students to specialize given the project's scope and complexity. He only used the final report from the team to assess the project; he had no way of knowing if students learned about aspects of the project outside their area of contribution.

After the first year of study, faculty expected students to master engineering content beyond their functional role responsibilities. Yet, most only required a final report that masked individual contributions and individual learning. Efforts to promote broader learning such as rotating the leaders may help, but there are no mechanisms in place to test or measure that benefit. Most of the faculty members interviewed were eager for ideas on how to encourage and measure student learning through project teams.

"Proceedings of the 2005 American Society for Engineering Education Annual Conference \& Exposition Copyright (C) 2005, American Society for Engineering Education” 


\section{Specialization}

In the first-year class, it was too soon for a student to be identified as a specialist (see Table 6). Students had a variety of skills and backgrounds that contributed differentially to a project, but those talents did not narrowly define them. The instructor found that students with some expertise were interested in challenging themselves by going beyond the minimum expectations of the assignment. At this stage the faculty member noted functional roles, but was not concerned about role specialization.

Assigning functional roles to specialists on the team contributes to efficiency, but could limit a student's future options. In the second-year class, the faculty member expressed concern that the specialty works to a student's advantage only when the talent is rare. When joined with a group of other people with the same specialty, the student is stuck. Interestingly, this faculty member commented on the disadvantage to the student who no longer has a special talent to offer. Yet, in such settings the student might be prompted to develop new skills and expand his or her learning. Although ensuring all students have mastered all engineering skills is a noble goal, this instructor noted that the quantity of engineering content that must be shared prevents teaching everyone how, for example, to use Pro-Engineer. Still, he was trying a new approach to teaching a computer program that required individual exercises to improve the odds that all students acquire this programming skill.

In the third-year course, students' mastery of the statistical techniques taught in class were tested. Since the project tapped a subset of the overall skills taught in the course, it offered an integrative opportunity. There was no direct measure of this integrative learning, but there was evidence of individual mastery of the statistical tools via examinations.

In the capstone project, specialization was expected given the complex nature of the task. The capstone instructor lamented the trade off between efficiency and learning. At the brainstorming stage of project development it appeared everyone on a team contributed equally. However, other special skills such as drawing using Pro-Engineer or doing calculations tended to be delegated to the known experts in those areas. Although this faculty member wished everyone had these skills, he was resigned to the fact that they do not and focused instead on whether or not students divided the workload fairly.

\section{Implications}

These data revealed that students on engineering project teams divided their work load among functional roles that were assigned based on interest or known strengths. Many students assumed similar functional roles across team experiences within mechanical engineering, leading to their development as a specialist. Faculty, by and large, acknowledged that this specialization occurs and support it as an efficient approach to completing the team's project assignment. When pressed, faculty in the second, third, and fourth-year courses confessed that they have no way of knowing if their learning goals for individual students are being met through the project assignment. As students reported, when the quality of the overall product and meeting deadlines are viewed as most important, individual learning is relegated to those portions of the project to 
which one has directly contributed. As an unfortunate result, not all team members learned all the engineering content that was encountered during their team project.

Although faculty were aware of this specialization, they felt perplexed about how to respond. One interpretation of these data was to challenge the adoption of the industry team model in a classroom setting at all levels of the curriculum. Projects designed to imitate "real world" problems can never capture the instability inherent in industry. By definition, the educational environment is bounded and controlled. Whether explicitly taught or tacitly assumed, students are internalizing the message that product is more important than process. They are embracing the efficiency model because it works. Is learning compromised? It is clear that students recognize that they are not mastering every aspect of a project; they do not have to in order to be successful.

Engineering educators must be attentive to the specialization that is emerging on their project teams. There may be times when specialization is appropriate and encouraged. For example, one could make the case that the senior capstone experience offers such an opportunity. In courses leading to the capstone, however, faculty need to examine project assignments and consider how they fit in with other learning expectations throughout the curriculum. An intentional progression of course content and project skill development could mediate this premature specialization in students.

\section{Conclusion}

This progression across the mechanical engineering curriculum toward more intentional and refined specialization is incompatible with the learning goals engineering educators had for these team project assignments. First-year students offered their talents to their team, but were not yet labeled as specialists. As projects became increasingly complex and modeled on the "real world," the threat of specialization increased. At a prescribed point in a curriculum, it is appropriate to encourage the development of specialization but premature specialization can limit student learning. Is it possible to control the structure of the project team task and its assessment so that individual learning can be measured? The student participants, especially the team of juniors, had interesting ideas about how faculty can hold them more accountable for the engineering material explored through the team project. Is it possible to control the assumption

of roles on a team so that the students' learning of all content is assured? Rotating the leadership role offers one example of this type of manipulation that shows promise. What strategies might be developed to ensure functional roles are shared more broadly? Setting clear expectations and clear learning goals are recommendations from the learning and assessment literature as important first steps in improving student learning. Can engineering educators identify course content that should not be delegated to a team specialist? Or, can there be opportunities for students to develop multiple specialties or might specialists make sense in some contexts? Is it possible to implement multidisciplinary and/or multi-semester courses, building intentional specialization into a project requirement as demonstrated in a few programs highlighted at the beginning of this article?

Perhaps the team project has become so commonplace in typical engineering courses that educators have failed to attend to the nuances of this curriculum innovation. Projects are now

"Proceedings of the 2005 American Society for Engineering Education Annual Conference \& Exposition Copyright (C) 2005, American Society for Engineering Education” 
embedded into course syllabi, but learning demands more than simply their presence in the curricula. This study, and the positive reports on multidisciplinary, multi-semester projects that are emerging, should be a wake up call for all engineering educators to reexamine the project team experience for signs of premature specialization. As this study makes clear, faculty need guidance in how to modify the team experience to improve individual student learning and individual accountability for the learning. The engineering student project is such a rich and powerful learning tool that faculty must be attentive to how it is used in the service of student education. Opportunities for individual learning in projects should not be left to chance.

\section{Acknowledgement of Support}

The material is based upon work supported by the National Science Foundation under grant No. DUE-0243265: "A Pilot Investigating Functional Roles on Engineering Student Teams: Prelude to Assessment."

Any opinions, findings, and conclusions or recommendations expressed in this material are those of the authors and do not necessarily reflect the views of the National Science Foundation.

\section{References}

1. Barra, R. (1993). Tips and techniques for team effectiveness. Barra International, New Oxford, PA: Barra International.

2. Belenky, M. F., Clenchy, G. M., Goldberger, N. R., \& Tarule, J. M. (1986). Women's ways of knowing: The development of self, voice and mind. New York: Basic Books.

3. Fullilove, R., \& Treisman, P. U. (1990). Mathematics achievement among African American undergraduates at the University of California Berkeley: An evaluation of the math workshop program. Journal of Negro Education, 59 (3): 463.

4. Smith, K. A., \& Waller, A. A. (1997). Cooperative learning for new college teachers. In W. E. Campbell \& K. A. Smith (Eds.) New Paradigms for College Teaching (p. 185-309). Edina, MN: International Book Company.

5. Wankat, P. C., \& Oreovicz, F. S. (1993). Teaching engineering. New York: McGraw-Hill.

6. Lent, R., Schmidt, J., Schmidt, L., Glouster, C., \& Mouring, S. (2004). Relation of collective efficacy beliefs to group cohesion and performance in student project teams. Paper presented at the American Society of Engineering Education (ASEE) Annual Conference and Exposition, Salt Lake City, UT.

7. Slivovsky, L. A., DeRego, F. R., Zolotowski, C.B., Jamieson, L. H., \& Oakes, W. C. (2004). An analysis of the reflection component in the EPICS model of service learning. Paper presented at the American Society of Engineering Education (ASEE) Annual Conference and Exposition, Salt Lake City, UT.

8. Marchese, A. J., Schmalzel, J. L., \& Weaver, K. M. (2004). Creating an entrepreneurial culture at a startup engineering program. Paper presented at the American Society of Engineering Education (ASEE) Annual Conference and Exposition, Salt Lake City, UT.

9. Alford, K. L. (2004). Multidisciplinary computer science design projects. Paper presented at the American Society of Engineering Education (ASEE) Annual Conference and Exposition, Salt Lake City, UT.

"Proceedings of the 2005 American Society for Engineering Education Annual Conference \& Exposition Copyright (C) 2005, American Society for Engineering Education” 
10. Gibbs, A. (1997). Focus groups. Social Research Update, 19, Conducted for the Department of Social Medicine at Briston University.

11. Rees, F. (1997). Teamwork from start to finish. San Francisco: Jossey-Bass.

12. Knecht, R. (2004). Can peers be used effectively to assess teams? Paper presented at the American Society of Engineering Education (ASEE) Annual Conference and Exposition, Salt Lake City, UT.

13. McGourty, J., \& De Meuse, K. (2000). The team developer: An assessment and skill building program. New York: John Wiley \& Sons Press.

14. Macdonnell-Laeser, M., Moskal, B. M., Knecht, R., \& Laisch, D (2001). The engineering process: examining male and female contribution. Paper presented at the ASEE/IEEE Frontiers in Education Conference, Reno, NV.

15. Brown Leonard, J., Schmidt, J.A., Smith, P.E., \& Schmidt, L.C. (2004). A pilot study of functional roles on engineering student teams. Paper presented at the American Society of Engineering Education (ASEE) Annual Conference and Exposition, Salt Lake City, UT.

16. Johnson, P (1999). Problem-based, cooperative learning in the engineering classroom. Journal of Professional Issues in Engineering Education and Practice, January.

17. Vaughn, S., Schumm, J.S., and Sinagub, J. (1996). Focus group interviews in education and psychology. Thousand Oaks, CA: Sage.

18. ASA Series (1997). What is a survey? Produced by Section on Survey Research Methods, American Statistical Association.

19. Baxter Magolda, M. B. (1992). Knowing and reasoning in college: Gender related patterns in students' intellectual development. San Francisco: Jossey-Bass.

Biographical Information

JEANNIE BROWN LEONARD, M.Ed., is the ASA Project Coordinator. She oversees the data collection and analysis including scheduling and conducting focus groups as well as editing and coding transcripts. Her primary research interest is student intellectual development and integrative learning. Ms. Brown Leonard is currently pursuing a Ph.D. in Counseling and Personnel Services at the University of Maryland.

LINDA C. SCHMIDT, Ph.D., Associate Professor, Mechanical Engineering, A. James Clark School of Engineering, University of Maryland. Dr. Schmidt is the PI of the ASA project. In addition to the current project, she actively supports women and minorities in engineering, provides team training for engineering students and faculty, studies engineering design processes, generative design methods, and design rationale capture.

PAIGE E. SMITH, Ph.D., Director of the Women in Engineering Program, A. James Clark School of Engineering, University of Maryland. Dr. Smith is a co-PI of the ASA grant. She provides leadership in recruiting and retaining female engineering students for the college. Her current research focuses on engineering design teams and project management.

JANET A. SCHMIDT, Ph.D. Dr. Schmidt is the co-PI of the NSF sponsored ASA grant. A licensed psychologist, she is the Director for Interdisciplinary Research in the College of Education at the University of Maryland. Her other interests include teamwork training for faculty and students in engineering and assessment activities related to ABET and NCATE accreditation.

"Proceedings of the 2005 American Society for Engineering Education Annual Conference \& Exposition Copyright (C) 2005, American Society for Engineering Education” 


\section{Appendix}

Table 1: Functional Roles

\begin{tabular}{|l|l|}
\hline ENES 100 & Programmer; Builder; Photographer; Wiring person; Report writer; Web site developer \\
\hline ENES 220 & Designer; Drawer; Assembler/Builder; Problem solver; Calculator \\
\hline ENME 392 & Gantt chart maker; Scheduler; Data analyst/Number cruncher; Calculator \\
\hline ENME 472 & Researcher; Project manager; Techies; Reviewer \\
\hline
\end{tabular}

Table 2: Learning

\begin{tabular}{|c|c|}
\hline & $\begin{array}{l}\text { Learning depends on teachers } \\
\text { - "In AP Physics we spend like, a good month or more learning all that stuff, and the teacher really was just } \\
\text { like, 'here is the equation, figure it out!'... it didn't seem like she really taught us enough beforehand on } \\
\text { some of the more theoretical things." } \\
\text { - "I feel like I am paying for my education so I want someone to teach me because I'm paying for it and I'm } \\
\text { not really a hands-on person." } \\
\text { Beginning to take some responsibility for learning } \\
\text { - "Not all the professors are going to teach you. So you have to go and learn for yourself." } \\
\text { - "If there is something that I need to know, I go out and learn it myself. And I end up relating it back to the } \\
\text { group." } \\
\text { Nature of team project learning } \\
\text { - "I think this is the case in most group projects. It's really two kinds of hats where you learn one thing in } \\
\text { class and you learn another thing in the group." } \\
\text { "I mean a lot of brainstorming....you gain new experiences and new knowledge by just sitting around } \\
\text { talking about it." } \\
\text { Peers can potentially contribute to learning } \\
\text { - "If someone needs to know something, yes, they have the motivation to go learn it, but they'll check } \\
\text { around first because inevitably somebody else is a little bit familiar with it." } \\
\text { " "You get to see how other people do stuff. You can...try to do things yourself that way." } \\
\text { Learning about teamwork } \\
\text { - "I think I've learned more about being on a team than any kind of academic information so far." } \\
\text { - "It's a very good opportunity to learn about, like, teamwork and how people interact on a team." }\end{array}$ \\
\hline $\begin{array}{l}\text { N } \\
\text { N } \\
\sum_{-1}\end{array}$ & $\begin{array}{l}\text { Courses offer tools to complete project } \\
\text { - "The relationship between the project and the course is that of tools. The course gives you the knowledge } \\
\text { of how to use the tools." } \\
\text { - "The material taught in the course is kind of a foundation for using it in real life, and then these kinds of } \\
\text { projects are kind of building on top of that... applying the course material." } \\
\text { Learning can be compromised } \\
\text { - "Some of that's [learning] dependent on how much time you have to do the project. I know that some } \\
\text { projects I've done in the past, there is such a short timeframe that we just were so worried about meeting } \\
\text { the specifications of the project and we didn't really understand, like, exactly what we were doing." } \\
\text { - "He [the instructor] doesn't know [if a student learned all the material]. And half the time I don't learn the } \\
\text { stuff or I don't really truly understand the stuff until I continue on to a different class." } \\
\text { Peers can contribute to learning } \\
\text { - "If they [team members] don't understand the material, I tend to just try to...help them along. } \\
\text { - "I think that's really valuable, being able to see how someone else works out a problem." } \\
\text { Suggestions for improving student learning in project teams } \\
\text { - "Maybe if he [the instructor] did an interview with each group." } \\
\text { - "Maybe require that somebody present a part of the project that they didn't - weren't the main contributor } \\
\text { to or something of that nature." } \\
\text { - "The fact that you have the specialist on your team is actually great - would be a great boon if you can use } \\
\text { them correctly...If you can cause an interaction or even perhaps not assign them to their area of specialty } \\
\text { or have them as like a backup to help someone else specifically assigned to them, then the learning process } \\
\text { would be greatly augmented." }\end{array}$ \\
\hline
\end{tabular}

"Proceedings of the 2005 American Society for Engineering Education Annual Conference \& Exposition Copyright (C) 2005, American Society for Engineering Education” 
Table 2: Learning

\begin{tabular}{|c|c|}
\hline & $\begin{array}{l}\text { Courses offer tools to complete project } \\
\text { - "We're more or less using everything we are learning." } \\
\text { - "Whoever ends up doing the brunt of the calculation work for this project, they will learn the most about } \\
\text { statistics for this class." } \\
\text { - "I don't have to understand all the concepts to find out which one we could use for a project." } \\
\text { Learning linked to process and product } \\
\text { - "The scope of the projects has gotten much more difficult from freshman year until now...our projects } \\
\text { have gone from things that most likely will fail, to projects that will, at the end of it...would work in a real } \\
\text { situation." } \\
\text { - "I think it's important for the professors and teachers to - in dealing with the projects - not so much to } \\
\text { look at the success of the project, but to look at the success of the learning within the project." } \\
\text { - "If you're just trying to get a good end result, it is better to be specialized, but we don't go to [this } \\
\text { university] to pump out little statistical things. We're here to learn stuff." } \\
\text { Peers contribute to learning } \\
\text { - "Someone who is honestly committed to the project, I definitely value their opinion or try and help them } \\
\text { along, because it helps you learn more. I mean, if you can understand the material well enough to explain } \\
\text { it to someone else, then you have a fairly good grasp on what you're trying to learn." } \\
\text { Learning about teamwork } \\
\text { - "Learned how to work in groups...I think one of the biggest things we're learning in engineering is how to } \\
\text { work in teams." } \\
\text { "They're basically trying to teach us teamwork because nobody's going to know everything." }\end{array}$ \\
\hline & $\begin{array}{l}\text { Learning linked to team formation } \\
\text { - "I immediately go for people... who have skills in an area where I know I am weak....you can learn } \\
\text { something from them." } \\
\text { - "Having team members who know certain skills helps others learn." } \\
\text { Course and project are integrated } \\
\text { - "It is just becoming evident that we are going to need a lot of stuff from other classes. For the upcoming } \\
\text { report, we need to do stuff we haven't done in three years." } \\
\text { - "We had ideas [for this project] and he [the instructor] had to approve one, he was checking the idea and } \\
\text { finding that, okay, to do that product you are going to need this amount of knowledge from other classes. } \\
\text { He wanted to see if it was complex enough." } \\
\text { Less patience with peers needing help } \\
\text { - "We don't mind explaining things to you, but this time you try to explain it." } \\
\text { - "No, we don't mind but... we need to get our work done and then there's somebody else that wants you to } \\
\text { explain." } \\
\text { Time constraints interfere with learning } \\
\text { - "This project is time consuming, but other projects are also time consuming. So the time constraint is } \\
\text { definitely a problem." }\end{array}$ \\
\hline
\end{tabular}

"Proceedings of the 2005 American Society for Engineering Education Annual Conference \& Exposition Copyright (C) 2005, American Society for Engineering Education" 
Table 3: Role Specialization

\begin{tabular}{|c|c|}
\hline 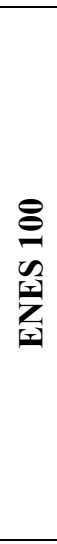 & $\begin{array}{l}\text { Fill roles related to strengths } \\
\text { - "One of our teammates is really good at one aspect such as programming and another team member was } \\
\text { good at building the weather station." } \\
\text { - "It helps that a lot of our group had prior knowledge of things going into [the project]...we had someone } \\
\text { who could already program, do the web page, do the wiring." } \\
\text { Specialists enhance overall product } \\
\text { - "You can get each individual part done well with input from every other person who doesn't have that } \\
\text { specialty." } \\
\text { - "We each know a different area that we can concentrate on. If I was doing it all by myself, I wouldn't } \\
\text { know where to start." } \\
\text { Team members can learn from specialists } \\
\text { - "This is a first where I've had a group where other people are specialized in that I can learn from a lot of } \\
\text { people in the group." }\end{array}$ \\
\hline 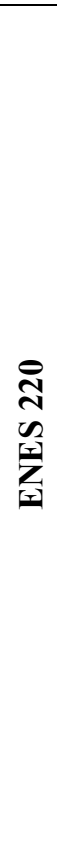 & $\begin{array}{l}\text { Fill roles based on strengths or interests } \\
\text { - "I'll go ahead and do this at home because I have maybe the means to do it at home... somebody had the } \\
\text { means, like, a lathe or a vice or something like that that they could use at home." } \\
\text { - "Usually when you're on a team, you're like, well, what do you like to do?... This is what has to be done. } \\
\text { So, if you like to do that, just go do it so we can get it done." } \\
\text { Specialists enhance overall product } \\
\text { - "They [specialists] can make it, like, look like a professional product and finish it off. I don't know how it } \\
\text { [having specialists] could be a disadvantage to the final product." } \\
\text { - "[A specialist] provides, you know, hopefully you're doing this so that at least that one part of the project } \\
\text { should be good." } \\
\text { Team members can learn from specialists } \\
\text { - "If you are a specialist, it can be good because, one, hopefully the rest of your group can take a little bit } \\
\text { away from, you know, your increased knowledge of the subject." } \\
\text { - "If you can cause an interaction or even perhaps not assign them to their area of specialty or have them as } \\
\text { like a backup to help someone else specifically assigned to them, then the learning process would be } \\
\text { augmented." } \\
\text { Specialization has costs } \\
\text { - "A lot of times that [having specialists] could be a disadvantage, just because you don't get to learn the } \\
\text { other things that are outside your specialty." } \\
\text { "The disadvantage is the specialist has been taught in a specific manner, and to get to this point, they've } \\
\text { already made so many assumptions. What if you don't want to make those assumptions?" }\end{array}$ \\
\hline & $\begin{array}{l}\text { Some specialization works well } \\
\text { - "I think it helps to have - looking back - to have half the people on the team very specialized in either, } \\
\text { you know, in something like, maybe they're really good at the conceptual work...or really skilled with } \\
\text { doing like, computer design. And the other half it helps to have people that are very flexible." } \\
\text { - "It [being a specialist] is always going to be helpful." } \\
\text { Specialists enhance overall product } \\
\text { - "If you specialize you get good at it. When you turn in the final product, it should be pretty accurate." }\end{array}$ \\
\hline
\end{tabular}

"Proceedings of the 2005 American Society for Engineering Education Annual Conference \& Exposition Copyright (C) 2005, American Society for Engineering Education" 
Table 3: Role Specialization

\begin{tabular}{|c|c|}
\hline & $\begin{array}{l}\text { Recognize need to specialize } \\
\text { - "We started talking over the summer....and he said, 'I knew people who were really good at building stuff } \\
\text { and designing'...I like the process stuff...we kind of just brought it together that way." } \\
\text { - "We know that three people here really know how to do engineering drawings and that's who we assign } \\
\text { that to." } \\
\text { - "The roles fell into place....we found people's strengths and you know how people work." } \\
\text { Team approach is essential to some tasks } \\
\text { - "There were some things some of us knew about that the others would have completely passed over, had } \\
\text { no clue." } \\
\text { Specialization is efficient } \\
\text { - "It's not like we all go off in a separate little corner to do it...I'm not in my own little world doing it...we } \\
\text { - "Thet back together and all the different parts have to come back together." } \\
\text { definitely a problem [that affects how project is approached]" } \\
\text { Not everyone specializes } \\
\text { - "I consider myself a jack-of-all-trades because I know a little bit about a lot of things, but not an extreme } \\
\text { amount about any of them." }\end{array}$ \\
\hline
\end{tabular}

Table 4: Functional Roles

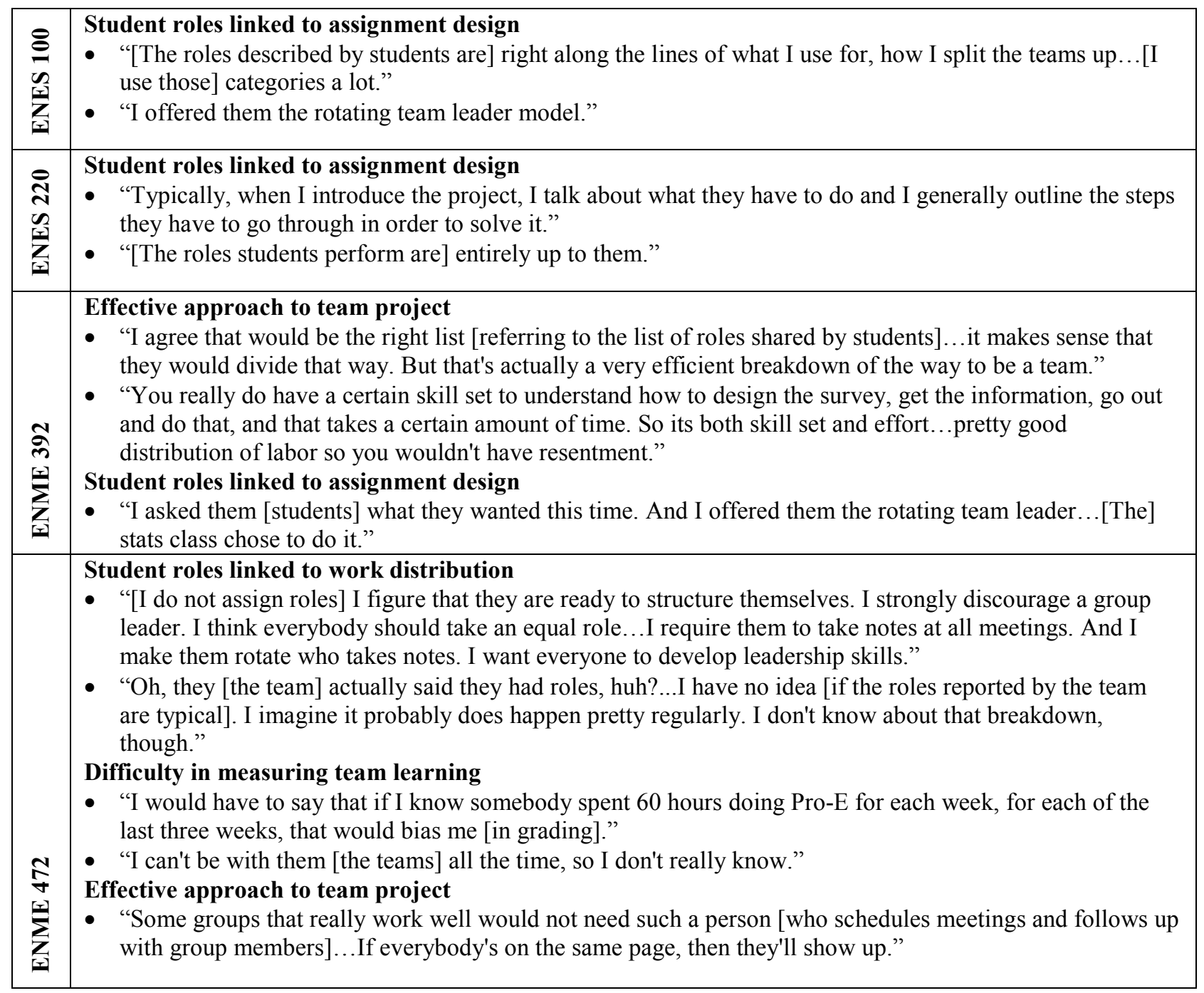

"Proceedings of the 2005 American Society for Engineering Education Annual Conference \& Exposition Copyright (C) 2005, American Society for Engineering Education" 
Table 5: Learning

\begin{tabular}{|c|c|}
\hline 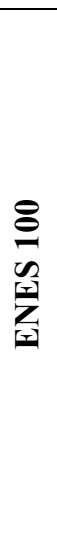 & $\begin{array}{l}\text { Expect broad conceptual learning } \\
\text { - "I didn't require that [for team members to learn each other's specialization]. I told them I did have an } \\
\text { expectation of a minimal across the board understanding of certain aspects of the project by all team } \\
\text { members...It doesn't matter if you're a civil engineer and are never going to plug in a volt meter, in this } \\
\text { course I want you to leave knowing a few basics that are broad." } \\
\text { Team project learning goals } \\
\text { - "The team learning maybe helped them get a little more of a sense of something that they really weren't } \\
\text { interested in." } \\
\text { - "I guess for at least some portion and some of the students, it's more interesting to learn something by } \\
\text { doing a project." } \\
\text { Methods of measuring team learning } \\
\text { - "So, having a midterm was really the only way of guaranteeing that all team members picked up the } \\
\text { material." }\end{array}$ \\
\hline 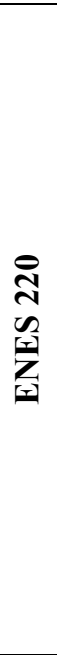 & $\begin{array}{l}\text { Students' perception of the team project } \\
\text { - "My take is that the students are going to think it's [a team project] a burden and that it takes away from the } \\
\text { other quantitative measures." } \\
\text { - "It seems as if the enthusiasm of the professor for the project also has something to do with how the } \\
\text { students perceive it...it seems like you get more complaints from students with professors who aren't fully } \\
\text { on board with the project than from others." } \\
\text { Effective approach to team project } \\
\text { - "There aren't any formal mechanisms [for making sure students share their specialized part of the project } \\
\text { with other team members]... I tell students], you work on the project, you should work with a couple of } \\
\text { people to check answers. I'm pretty sure, or I have a feeling, that that's not happening to the level I would } \\
\text { like it to...I'm finding, to my embarrassment, that many of the groups are making fundamental decision } \\
\text { errors that they just wouldn't...or I don't think they should be making." } \\
\text { Methods of measuring team learning } \\
\text { - "The project is due the last day of the class. And unless they see me next semester...they don't even know } \\
\text { how they did, or they don't even get to read through their project other than the grade I put up on the } \\
\text { website. So that's a problem." }\end{array}$ \\
\hline & $\begin{array}{l}\text { Effective approach to team project } \\
\text { - "For the teams that do the rotating positions [for leader], I know at some level they have to be responsible } \\
\text { for all of it for the two weeks they are 'it'... So good teams operate, not only in terms of the project, but } \\
\text { they operate in terms of the other things that are required in class." } \\
\text { Methods of measuring team learning } \\
\text { - "I don't know how much they all learn of the project." }\end{array}$ \\
\hline & $\begin{array}{l}\text { Effective approach to team project } \\
\text { - "There's so much to do that they have to break it up." } \\
\text { Team project learning goals } \\
\text { - "They [students] didn't even realize you had to think this carefully about solving a problem...So when they } \\
\text { realize how much it takes to develop one of these things and I think it is a big learning experience." } \\
\text { Methods of measuring team learning } \\
\text { - "If you talk about engineering, by which I mean analysis, then that's measuring the report. There is no test } \\
\text { on that." } \\
\text { - "I know generally who did the analysis because they come and ask me and so, of course, that's brownie } \\
\text { points." }\end{array}$ \\
\hline
\end{tabular}

"Proceedings of the 2005 American Society for Engineering Education Annual Conference \& Exposition Copyright (C) 2005, American Society for Engineering Education" 
Table 6: Role specialization

\begin{tabular}{|c|c|}
\hline 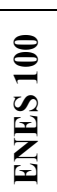 & $\begin{array}{l}\text { Specialization less pronounced } \\
\text { - "I'm sure in some teams, there were people who came in already knowing how to do electronics and...by } \\
\text { and large they actually wanted to push themselves so they made it more complicated than they needed, just } \\
\text { so they could try something new." }\end{array}$ \\
\hline & $\begin{array}{l}\text { Specialization costs and benefits } \\
\text { - "It's [specialization] good in that it can be very efficient. The students are working on their strengths. But } \\
\text { it's dangerous in a sense that they get pigeonholed into only being the drawer or only being the calculator. } \\
\text { They go to another class and they get put in with a bunch of other team members. Let's say we have team } \\
\text { with all calculators and no drawers, then they're going to be at a disadvantage." } \\
\text { - "There's so much other stuff for them to learn that there's not enough time to teach everybody Pro- } \\
\text { Engineer or everybody all these other topics they might not have." } \\
\text { Strategies to counter specialization } \\
\text { - "Even though they feel comfortable doing calculations, it might be good if they can expand their } \\
\text { knowledge base and try something different." } \\
\text {-I'm trying to change that a little bit this semester in my sections. We're requiring them to use the same } \\
\text { computer program...I'm going to give them little tasks that every student has to turn in throughout the } \\
\text { semester...So at the very least, you know, you don't have to say, 'Well, this person does the computer } \\
\text { work and I do something else'." }\end{array}$ \\
\hline 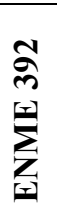 & $\begin{array}{l}\text { Strategies to counter specialization } \\
\text { - "What they are missing [by specializing] is the integration level, right? Because since there'll be quizzes } \\
\text { and tests on everything I teach, including every tool that they use in there, so at lease at some level I'm } \\
\text { guaranteed that they get a basic level of understanding of the tools." }\end{array}$ \\
\hline 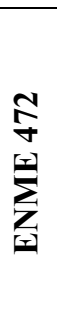 & $\begin{array}{l}\text { Specialization compromises learning } \\
\text { - "There usually turns out to be one or two people that are mathematically inclined, that tend to do that [the } \\
\text { stress analysis]. It usually turns out to be one or two people that are better at editing and writing. Well, I } \\
\text { really try to discourage having one person doing that...I really don't [want just one person to write it up]. } \\
\text { It's not fair." } \\
\text { - "I'd like them all to do the analysis too, but, I mean, you asked me what happens - that's what tends to } \\
\text { happen. As far as their brainstorming of ideas, it looks like everybody contributes to that equally." } \\
\text { - "[Pro-E/drawing] generally falls on a couple of people...It would be nice if everybody could draw." }\end{array}$ \\
\hline
\end{tabular}

"Proceedings of the 2005 American Society for Engineering Education Annual Conference \& Exposition Copyright (C) 2005, American Society for Engineering Education" 